\title{
Direct selection for phenotypic traits in carrot genotypes
}

\author{
Agnaldo DF de Carvalho1 ${ }^{\mathbb{D}}$; Giovani $O$ da Silva1 ${ }^{1 \mathbb{D}}$; Gabriel E Pereira ${ }^{2} \mathbb{D}$
}

'Embrapa Hortaliças, Brasília-DF, Brasil; agnaldo.carvalho@embrapa.br; giovani.olegario@embrapa.br; ${ }^{2}$ Universidade de Brasilia (UnB), Brasília-DF, Brasil; gb.emiliano28@gmail.com

\begin{abstract}
Selection of more productive carrot genotypes is fundamental for crop breeding programs aiming to increase productivity and reduce cost production. Thus, the aim of this work was to evaluate gains from direct selection and to measure its effects on other agronomic traits of interest in carrots. Thirty six carrot genotypes were evaluated in two experiments: the first, sown in the second half of November 2016 and the second one in the first week of March 2017. The experimental plots covered a useful area of $1.5 \mathrm{~m}^{2}$, in transversal rows and 0.10 $\mathrm{m}$ double spacing between single rows $\mathrm{x} 0.20$-m between double rows in a randomized block design with 3 replicates. At 90 days, the incidence of leaf blight was evaluated using a note scale and 100 days after sowing, roots were harvested measuring the number and mass of total, commercial and non-commercial roots of each plot. The direct selection of commercial root mass allowed to estimate indirect and expressive gains for most evaluated traits, allowing to select seven genotypes (populations 758, 751, 737, 736, 735, 744 and 742) which can be released as cultivar or for the formation of a broader genetic-based population.
\end{abstract}

Keywords: Daucus carota, efficiency, correlation.

\section{RESUMO}

\author{
Seleção direta para caracteres fenotípicos em genótipos de \\ cenoura
}

A seleção de genótipos de cenoura mais produtivos é fundamental para os programas de melhoramento dessa cultura visando aumento na produção com redução dos custos. Assim, objetivou-se com esse trabalho avaliar o ganho com a seleção direta e medir seus efeitos em outras características agronômicas de interesse em cenoura. Para isso, 36 genótipos de cenoura foram avaliados em dois experimentos, sendo o primeiro semeado na segunda quinzena de novembro de 2016 e o segundo na primeira semana de março de 2017. As parcelas experimentais possuíram área útil de $1,5 \mathrm{~m}^{2}$, em fileiras transversais e espaçamento duplo $0,10 \mathrm{~m}$ (entre linhas simples) x $0,20 \mathrm{~m}$ (entre linhas duplas) no delineamento de blocos casualizados com três repetições. Aos 90 dias avaliou-se a incidência de queima das folhas por escala de notas e aos 100 dias após a semeadura, realizou-se a colheita das raízes, mensurando o número e massa das raízes, total, comercial e refugo de cada parcela. A seleção direta no caráter massa de raízes comerciais possibilitou estimar ganhos indiretos e expressivos para a maioria dos caracteres avaliados, permitindo assim, selecionar sete genótipos (populações 758, 751, 737, 736, 735, 744 e 742) os quais podem ser validados para lançamento ou para formação de uma população de base genética mais ampla.

Palavras-chave: Daucus carota, eficiência, correlação.

\section{Received on November 6, 2018; accepted on August 2, 2019}

$\mathrm{C}$ arrot occupies a prominent place among the vegetables grown in Brazil. Estimates of this tuberous vegetable production are superior to 700 thousand tons per year. The main production regions are Minas Gerais, Paraná, Bahia and Rio Grande do Sul, considering the region of São Gotardo, located in Alto Paranaíba Mineiro, responsible for approximately half of all carrot produced in Brazil, supplying most Brazilian's Southeast, Midwest, North and Northeast (IBGE, 2018).

Currently, carrot breeding programs aim to develop mainly hybrid cultivars. Although market has focused on this type of cultivar; multi-character selection in breeding base populations is an important phase in breeding programs (Carvalho et al., 2016).

According to Goldenberg (1968), selection for a specific trait provides changes in other traits, in relation to genetic correlations. This fact is called "correlated response to selection", considering that this selection sometimes does not interest the breeder. Quantifying the magnitude of this correlated response, also called indirect selection is of great importance considering low-heritability or difficultto-measure or difficult-to-identify traits.

For Cruz \& Carneiro (2003), direct selection is carried out by a breeder when the aim is to obtain gains for an isolated trait. However, this selection can provide indirect desirable and undesirable gains for other traits depending on the correlation degrees between the traits under selection. Depending on the intensity degree of trait changes in certain population, this population can be seriously compromised, to the point of being rejected by the market.

Direct and indirect selections are the first options for obtaining rewarding gains (Martins et al., 2003). Direct selection for carrot was studied by Carvalho et al. (2017) in an experiment evaluating open pollinated cultivars and carrot hybrids, verifying that, direct selection is effective for traits which are positively correlated.

Given the above, this study aimed 
to evaluate gains from direct selection for commercial root mass (CRM) and measure the effect of these gains on other agronomic traits of interest in carrot.

\section{MATERIAL AND METHODS}

Experiments were installed in field at Embrapa Hortaliças (15'55'44"s; 4808'35'”; $1000 \mathrm{~m}$ altitude), located in the rural area Ponte Alta. Thirty six carrot genotypes were evaluated in two experiments: the first one was sown in the second half of November 2016 (total rainfall $840 \mathrm{~mm}$ and averge temperatura $20.24^{\circ} \mathrm{C}$ during the experiment), the second one in the first week of March 2017 (total rainfall $240 \mathrm{~mm}$ and averge temperatura $20.37^{\circ} \mathrm{C}$ ). The local climate is Aw type, tropical with dry winter, according to Köppen-Geiger classification. The soil in the experiental area was classified as typic distrophic Red Latosol, clayey texture.

For planting, the area which was under fallow with cultural remains of carrots from the previous year, was desiccated with non-selective herbicide and incorporated in plowing operation, 60 days before planting. One week before planting each experiment, soil was harrowed with a disc chisel; on the planting day of the experiments, beds were formed by bed former machine.

Three months before experiment installation, the soil was evaluated: $\mathrm{pH}=6.0 ; \mathrm{P}=12.0 ; \mathrm{K}=399.0 ; \mathrm{Na}=41.0$, organic matter $=267.0 ; \mathrm{B}=0.18 ; \mathrm{Cu}=$ 3.30; $\mathrm{Fe}=57.2 ; \mathrm{Mn}=69.7 ; \mathrm{Zn}=8.1$ and $\mathrm{S}=2.7$; in $\mathrm{mg} \mathrm{dm}^{-3}$, except $\mathrm{pH}$. Values of $\mathrm{Ca}=3.3, \mathrm{Mg}=1.5, \mathrm{Al}=0.0 ; \mathrm{H}+\mathrm{Al}=$ 3.7 , in $\mathrm{cmol}_{\mathrm{c}} \mathrm{dm}^{-3}$. Thus, limestone was not applied, and planting fertilization was performed using $1300 \mathrm{~kg} \mathrm{ha}^{-1}$ (52 $\mathrm{kg} \mathrm{ha}^{-1} \mathrm{~N}, 182 \mathrm{~kg} \mathrm{ha}^{-1} \mathrm{P}_{2} \mathrm{O}_{5}$ and $104 \mathrm{~kg}$ $\mathrm{ha}^{-1} \mathrm{~K}_{2} \mathrm{O}$ ) of commercial formula 04-1408 (N-P-K).

The following 36 summer carrot genotypes belonging to Embrapa and resistant to leaf blight were evaluated: 734, 735, 736, 737, 738, 739, 740, 741, 742, 743, 744, 745, 746, 747, 748, 749, $750,751,752,753,754,755,755,758$, $1413,708 * 555-60-1,710 * 555-60-1$, 710*588-11-4, 731*555-7-1, Alvorada,
Brasília, GL-756 and BRS Planalto; from Horticeres cv. Carandaí; from ISLA Sementes the cv. Suprema and from Vilmorin cv. Verano. Experimental plot consisted of a 1.5-m-long x 1-m-wide seedbed. Seeds were manually sown in furrows, transversal to the seedbed, double spacing $10 \times 20 \mathrm{~cm}, 10 \mathrm{~cm}$ between simple rows and $20 \mathrm{~cm}$ between double rows. Experimental design was randomized blocks with three replicates. Plants were irrigated through conventional sprinkler, in order to meet the crop demand in periods of rain scarcity. Plants were thinned 30 days after sowing to leave a population of 600 thousand plants per hectare. Top dressing fertilization was done right after thinning at $400 \mathrm{~kg} \mathrm{ha}^{-1}$ of ammonium sulfate $\left(80 \mathrm{~kg} \mathrm{ha}^{-1} \mathrm{~N}\right)$. Other cultural practices were those normally used for carrot cultivation in the Brazilian Savannah (Cerrado) Region (Filgueira, 2003).

At 90 days after planting (DAP), the severity of leaf blight (SLB) attack was evaluated, graded by two evaluaters independently, using note scale from 1 to 5, adapted by Aguilar et al. (1986), considering $1=$ severity $>90 \%, 2=$ severity from 50 to $90 \%, 3=$ severity from 12.5 to $50 \%, 4=$ severity from 3.8 to $12.55 \%$ and $5=$ severity $<3.8 \%$.

Roots were harvested 100 DAP and values of different traits converted to $\mathrm{t} \mathrm{ha} \mathrm{a}^{-1}$ or number of roots $\times 10^{3} \times \mathrm{ha}^{-1}$, considering effectiveness 1.5 -m-wide seedbed: $1-\mathrm{m}$ seedbed, plus $0.5 \mathrm{~m}$ of the walkway formed by the tractor wheels. Measurements, carried out in laboratory, of the following traits were: total root mass (TRM, $\mathrm{t} \mathrm{ha}^{-1}$ ), weighing all the harvested roots in plots using a digital scale; commercial root mass $\left(\mathrm{CRM}, \mathrm{t} \mathrm{ha}^{-1}\right)$, weighing roots without external defects and showing diameter higher than $25 \mathrm{~mm}$ and length over 12 $\mathrm{cm}$; non-commercial root mass (NRM, $\mathrm{t}$ $\mathrm{ha}^{-1}$ ), using the difference between TRM and CRM; number of commercial roots (NCR, number of roots ha-1 $\mathrm{x} 1000$ ) by counting roots without defects and diameter higher than $25 \mathrm{~mm}$ and length over $12 \mathrm{~cm}$; number of total roots (NTR, number of roots ha-1 $\mathrm{x}$ 1000) counting all the roots harvested in the plot; number of non-commercial roots (NNR) by the difference between NTR and NCR; $\mathrm{CRM}$ /TRM ratio (PROP), root average mass (RAM, in grams) using TRM/ NTR ratio and commercial average mass (CAM, in grams) using CRM/NCR.

After checking the assumptions of the variance analysis, analyzes and sources of variation were tested by $F$ test. Heritability estimates $\left(\hat{h}^{2}\right)$ and selection gains were calculated using the following estimators:

$$
\hat{h}^{2}=\frac{\hat{O}_{g}^{2}}{\hat{O}_{\bar{F}}^{2}} \times 100
$$

and gains from selection:

$$
\mathrm{GS}=i \hat{h}^{2} \hat{O}_{\overline{\mathrm{F}}}
$$

in which: $i=$ selection index based on phenotypic standard deviation; $\hat{h}^{2}$ : heritability in the broad sense in the average genotype and $\hat{o}_{F}$ : phenotypic standard deviation based on average of genotypes.

All analyses were performed using Genes VS 2013.5.1 computational application (Cruz, 2013).

\section{RESULTS AND DISCUSSION}

A difference among genotypes was verified for leaf blight (SLB), showing variability for this trait in the set of carrot genotypes evaluated. In relation to difference between environments, differences between the two evaluation times were verified, which shows that different times influence on the behavior of the evaluated carrot genotypes. In relation to interaction between genotypes $\mathrm{x}$ environments (GxE) no significant difference was noticed by F test, for traits SLB, non-commercial root mass, number of commercial roots (NCR), number of non-commercial roots (NNR), commercial mass/total root mass ratio (PROP), average mass of total roots (TAM) and average mass of commercial roots (CAM) showing that different times do not influence the expression of these traits.

In relation to total root mass (TRM), commercial root mass (CRM) and number of total roots significant differences were observed $(\mathrm{P}<0.05)$ for interaction between GxA. This fact shows the variability among genotypes and that these genotypes 
express differently, depending on the evaluated time. RAM showed highly significant differences between genotypes and environments, but no significant difference was noticed for interaction between GxA; this fact shows that the interaction changes genotype classification in different environments in relation to production of total and commercial roots, but the same is not true for non-commercial root mass. The first experimental time was characterized by the beginning of rainy season, with still little rainfall and mild night temperatures. The second experimental time is characterized by heavier rainfall and higher temperature. High interference between environments changing the classification of carrot genotypes was also verified by Silva et al. (2011) evaluating seven carrot genotypes in 5 environments in two agricultural years. In another study carried out by Grangeiro et al. (2012), eight carrot cultivars originated from cultivar Brasilia were evaluated. These cultivars were commercialized by different seed companies, in MossoróRN, from August to November in 2007 and 2008. These authors verified a complex interaction, it means, change in genotype classification for commercial root mass.

The coefficients of experimental variation ranged from $5.37 \%$ for SLB to $25.83 \%$ for NCR. These values are suitable for experiments with carrots for Brazilian conditions (Carvalho et al., 2017; Oliveira, et al., 2008). CVg/ CVe ratio, measured to show if a trait has favorable or unfavorable condition for selection (Cruz et al., 2012), ranged from 0.26 for NTR to 0.88 for CRM. These authors report that favorable condition for selection represent values close to or above the unit. For a set of evaluated traits, many traits do not show this condition. The most favorable ones for this selection are CRM, which is the most important trait in this study, and TRM.

In Table 1 are shown averages of traits under selection. From the 36 evaluated genotypes, the direct selection for CRM was $26.09 \mathrm{t} \mathrm{ha}^{-1}$ in average, whereas the seven selected populations $(758,751,737,736,735,744$ and 742) by direct selection presented an average of $35.35 \mathrm{t} \mathrm{ha}^{-1}$. A gain of $29.17 \%$ of improved population was estimated in relation to the average of original genotypes. Using CRM as a selected trait, the effects of this selection on other traits were estimated: $5.58 ; 19.39$;

Table 1. Direct selection gains in commercial root mass (CRM, $\left.\mathrm{t} \mathrm{ha}^{-1}\right)$ and indirect gains in leaf blight (SLB, note); total root mass (TRM) and non-commercial (NNR) x 1000 ha $^{-1}$; $\mathrm{CRM}$ /TRM ratio (PROP); individual root average mass, considering all roots per plot (TAM) and considering only commercial roots per plot (CAM); evaluating 36 carrot genotypes in Distrito Federal during seasons 2016/17 and 2017/17. Brasília, Embrapa Hortaliças, 2017.

\begin{tabular}{lrrrrc}
\hline Trait & \multicolumn{1}{c}{ Xo } & \multicolumn{1}{c}{ Xs } & $\mathbf{h}^{\mathbf{2}} \mathbf{( \% )}$ & GS & GS (\%) \\
\hline SLB & 3.56 & 3.88 & 60.53 & 0.20 & 5.58 \\
TRM & 46.85 & 57.94 & 81.85 & 9.08 & 19.39 \\
CRM & 26.09 & 35.35 & 82.18 & 7.61 & 29.17 \\
NRM & 20.76 & 22.60 & 62.44 & 1.15 & 5.53 \\
NTR & 817.78 & 863.49 & 28.06 & 12.83 & 1.57 \\
NCR & 258.73 & 322.38 & 64.19 & 40.85 & 15.79 \\
NNR & 559.04 & 541.11 & 36.57 & -6.56 & -1.17 \\
PROP & 0.52 & 0.60 & 73.68 & 0.06 & 10.64 \\
TAM & 58.02 & 68.92 & 78.69 & 8.57 & 14.77 \\
CAM & 101.28 & 110.58 & 65.95 & 6.13 & 6.05 \\
\hline Total & & & & 79.92 & 107.32 \\
\hline
\end{tabular}

$\mathrm{X} 0=$ Initial averages of genotypes, $\mathrm{Xs}=$ averages of selected genotype, $\mathrm{h}^{2}(\%)=$ broad-sense heritability using percentage, $\mathrm{GS}=$ gains from selection and $\mathrm{GS} \%=$ gains from selection using percentage.
$5.53 ; 1.57 ; 15.79 ;-1.17 ; 10.64 ; 14.77$ and $6.05 \%$ for SLB, TRM, NRM, NTR, NCR, NNR, PROP, TAM and CAM, respectively. In this case, the direct selection was effective for selecting the best carrot genotypes, since it allows an increase of values for most agronomic important traits, besides contributing, at least to a small extent, to reduce the amount of non-commercial roots.

Estimated gains for root mass in this study are quite superior to real gains calculated by Silva \& Vieira (2010) and Silva et al. (2012a). In the first case, the authors obtained gains of $2.82 \%$ per selection cycle evaluating three carrot populations of Brasília group, selected on six selection cycles for traits which provided higher root productivity (thicker and longer roots). In the second study, the authors obtained gains of $0.97 \%$ with selection for root mass of two carrot populations during eight years in a row. These estimated direct gains are also quite superior to direct gains estimated by Silva et al. (2013) for root mass in selection of $30 \%$ of best plants of three populations from Brasília group, in a selection cycle, which was $0.55 \%$.

However, gains similar to this study for CRM were obtained by Carvalho et al. (2017), selecting three best populations among 11 evaluated carrot genotypes; in this case, possibly by the highest proportion of genetic variance over phenotypic variance showing heritability coefficient of $74 \%$ and $86 \%$ accuracy of selection, besides low coefficient of experimantal variation, $14.17 \%$. Thus, it was estimated that gains under selection are varied, depending on experimental accuracy resulting from genetic variability present among genotypes under selection.

More expressive values of gains estimated in the selection of 20 best families among 100 evaluated families of a population belonging to Brasília group, and $50 \%$ of best plants in families for commercial root mass, were obtained by Silva et al. (2012b), with values ranging from 11.41 and $15.09 \%$ between families and 2.75 to $11.41 \%$ within families. All these values show that estimated gains can vary a great deal and depend on the evaluated genetic material 
Table 2. Genotypic correlations between blight leaf incidence (SLB, note); total root mass (TRM); commercial (NCR) and non-commercial (NNR) x $1000 \mathrm{ha}^{-1}$; CRM/TRM ratio (PROP); total average mass, considering all roots per plot (TAM) and considering only commercial average mass (CAM); evaluating 36 carrot genotypes in Distrito Federal during seasons 2016/17 and 2017/17. Brasília, Embrapa Hortaliças, 2017.

\begin{tabular}{llllllllll}
\hline Trait & TRM & CRM & NRM & NTR & NCR & NNR & PROP & TAM & CAM \\
\hline SLB & $0.68^{* *}$ & $0.74^{* *}$ & $0.25^{* *}$ & $0.42^{* *}$ & $0.85^{* *}$ & $-0.38^{* *}$ & $0.76^{* *}$ & $0.62^{* *}$ & $0.45^{* *}$ \\
TRM & & $0.96^{* *}$ & $0.70^{* *}$ & $0.56^{* *}$ & $0.86^{* *}$ & $-0.25^{* *}$ & $0.72^{* *}$ & $0.94^{* *}$ & $0.90^{* *}$ \\
CRM & & & $0.47^{* *}$ & $0.39^{* *}$ & $0.95^{* *}$ & $-0.50^{* *}$ & $0.87^{* *}$ & $0.98^{* *}$ & $0.89^{* *}$ \\
NRM & & & & $0.78^{* *}$ & $0.27^{* *}$ & $0.49^{* *}$ & $0.04^{\text {ns }}$ & $0.46^{* *}$ & $0.56^{* *}$ \\
NTR & & & & & $0.43^{* *}$ & $0.56^{* *}$ & $-0.04^{\text {ns }}$ & $0.21^{* *}$ & $0.13^{*}$ \\
NCR & & & & & & $-0.51^{* *}$ & $0.89^{* *}$ & $0.84^{* *}$ & $0.66^{* *}$ \\
NNR & & & & & & & $-0.86^{* *}$ & $-0.57^{* *}$ & $-0.48^{* *}$ \\
PROP & & & & & & & & $0.87^{* *}$ & $0.69^{* *}$ \\
TAM & & & & & & & & & $0.95^{* *}$ \\
\hline
\end{tabular}

**, Significant using $t$ test, at 5 and $1 \%$ significance, respectively; ${ }^{\text {ns }}$ not significant.

and existence of genetic variability superior to environmental variability.

In relation to selection effect on commercial root mass for leaf blight (SLB), 5.58\%, Pereira et al. (2012b) calculated the direct gains under selection in three carrot populations for both traits and verified that in two populations showing higher genetic variability for these traits, gains of $7.17 \%$ and $11.01 \%$ for CRM and 11.35 and $23.76 \%$ for tolerance to SLB were possible; whereas considering a population with lower genetic variability these gains were $0.00 \%$ for SLB and 9.61 for CRM.

Despite the positive results of direct selection in the present study, Cruz et al. (2012) report that selection, based on only one trait, may result in a very positive result for this selected trait, but also may lead to unfavorable results for the other traits. Thus, the authors suggest the use of methods which consider combinations which provide more balanced gains in superior genotypes selection, such as nonparametric indices.

Table 2 presents genotypic correlations, which express association between two traits. These traits can be observed directly in the individual, among the evaluated traits. A strong and positive correlation between CRM and SLB (0.74), TRM (0.96), NCR (0.95), PROP (0.87), TAM (0.98) and CAM (0.89) can be noticed. This fact highlights the importance of CRM in selecting the best genotypes seeking formation of new base populations for breeding or for nomination as new candidates to be released as cultivars.

Genotypic correlation between CRM and SLB (0.74) is common in carrot trials, as defoliation caused by leaf blight affects productivity (Brito et al., 1997; Pereira et al., 2012a; Perrin et al., 2017). Defoliation caused by leaf blight reflects in lower productivity and root quality.

Direct selection on CRM provides considerable gains in almost every other traits related to production in the evaluated carrot genotypes. Among the seven genotypes (Xs) (Table 1) selected from the 36 evaluated genotypes (Xo) (Table 1), direct selection (GS\%) (Table 1) in CRM (29.17\%), provided indirect and high gains in TRM (19.39\%), NCR (15.79\%), PROP (10.64\%) and TAM (14.77\%). Direct selection also provided smaller gains, but favorable for SLB (5.58\%) and CAM (6.05\%) and undesirable for NRM $(5.53 \%)$, very small gains for NTR (1.57\%) and NNR (-1.17\%), both favorable to selection. Using these results, for the set of evaluated traits, direct selection for CRM provides indirect gains for all variables, except for NRM, able to be used in carrot breeding programs aiming to obtain superior populations.

\section{REFERENCES}

AGUILAR, JAE; REIFSCHNEIDER, FJB; ROSSI, PF; DELLA VECCHIA, PT. 1986.
Nível de resistência de cenoura a Alternaria dauci e interação com tratamento químico. Horticultura Brasileira 4: 19-22.

BRITO, CH; POZZA, EA; JULIATTI, FC; LUZ, JMQ; PAES, JMV . 1997. Resistência de cultivares de cenoura (Daucus carota) a queima-das-folhas durante o verão. Revista Ceres 44: 371-379.

CARVALHO, ADF; SILVA, GO. 2017. Divergência genética entre genótipos de cenoura através de caracteres agronômicos. agro@mbiente 11: 137-144.

CARVALHO, ADF; SILVA, GO; PEREIRA, RB. 2016. Capacidade de combinação de genitores de cenoura para caracteres de rendimento de raízes e tolerância a queima das folhas. Revista Ceres 63: 183-190.

CARVALHO, ADF; NOGUEIRA, MTM; SILVA, GO; LUZ, JMQ; MACIEL, GM; RABELO, PG. 2017. Seleção de genótipos de cenoura para caracteres fenotípicos de raiz. Horticultura Brasileira 35: 097-102.

CRUZ, CD; CARNEIRO, PCS. 2003. Modelos biométricos aplicados ao melhoramento genético. Viçosa: UFV. 579p.

CRUZ, CD; REGAZZI, AJ; CARNEIRO, PC. 2012. Métodos biométricos aplicados ao melhoramento genético $4^{\mathrm{a}}$ ed. Viçosa: UFV. $514 \mathrm{p}$.

CRUZ, CD. 2013. Genes: a software package for analysis in experimental statistics and quantitative genetics. Acta Scientiarum 35: 271-276.

FILGUEIRA, FAR. 2003. Novo manual de olericultura: agrotecnologia moderna na produção e comercialização de hortaliças. 2 ed. Viçosa: UFV. 421p.

GOLDENBERG, JB. 1968. El empleo de la correlación en el mejoramento genético de las plantas. Fitotecnia Latinoamericana, 5: 1-8.

GRANGEIRO, LC; AZEVÊDO, PE; NUNES, GHS; DANTAS, MSM; CRUZ, CA. 2012. Desempenho e divergência genética de cenoura 'Brasília' em função da procedência das sementes. Horticultura Brasileira 30: 137-142.

INSTITUTO BRASILEIRO DE GEOGRAFIA 
E ESTATÍSTICA, IBGE. 2018. Horticultura: número de estabelecimentos agropecuários e quantidade produzida por produtos da horticultura. Available: <https://www.ibge. gov.br/estatisticas-novoportal/economicas/ agricultura-e-pecuaria/21814-2017-censo-ag ropecuariohtml? $=\& \mathrm{t}=$ resultados $>$ Accessed: September 26, 2018.

MARTINS, IS; CRUZ, CD; REGAZZI, AJ; PIRES, IE. 2003. Eficiência da seleção univariada direta e indireta e de índices de seleção em Eucalyptus grandis. Revista Árvore 27: 327-333.

OLIVEIRA, CD; BRAZ, LT; BANZATTO, DA 2008. Adaptabilidade e estabilidade fenotípica de cultivares de cenoura. Horticultura Brasileira 26: 88-92.

PEREIRA, RB; CARVALHO, ADF; PINHEIRO, JB; SILVA, GO; VIEIRA, JV. $2012 \mathrm{a}$. Resistência de populações de cenoura à queima-das-folhas com diferentes níveis de germoplasma tropical. Horticultura Brasileira 30: 489-493.

PEREIRA, RB; SILVA, GO; PINHEIRO, JB; CARVALHO, ADF; VIEIRA, JV. 2012b. Herdabilidade e resposta à seleção para peso de raizes e tolerância a queima-das-folhas em populações de cenoura. Brasília: Embrapa Hortaliças. 17p. (Boletim de Pesquisa e Desenvolvimento, 81).

PERRIN, F; LAURENT, CD; GIBON, Y; CITERNE, S; HUET, S; SUEL, A; CLERC, VL; BRIARD, M; HAMAMA, L; PELTIER, D; GAGNE, S; GEOFFRIAU, E. 2017. Combined Alternaria dauci infection and water stresses impact carotenoid content of carrot leaves and roots. Environmental and Experimental Botany 143: 125-134.

SILVA, GO; VIEIRA, JV. 2010. Ganhos genéticos após seis ciclos de seleção em três populações de cenoura. Revista Ceres 57: 768-772.

SILVA, GO; CARVALHO, ADF; VEIRA, JV;
BENIN, G. 2011. Verificação da adaptabilidade e estabilidade de populações de cenoura pelos métodos AMMI, GGE Biplot e REML/ BLUP. Bragantia 70: 494-501.

SILVA, GO; VIEIRA, JV; CARVALHO, ADF. 2012a. Ganhos genéticos para caracteres de raiz em populações de cenoura nos sistemas orgânico e convencional de produção. Horticultura Brasileira 30: 473-479.

SILVA, GO; VIEIRA, JV; VILLELA, MS. 2012b. Dissimilaridade entre famílias e resposta correlacionada à seleção para caracteres de raiz de cenoura cultivada em dois sistemas de produção agroecológicos no Distrito Federal. Semina 33: 2115-2124.

SILVA, GO; VIEIRA, JV; CARVALHO, ADF; BOITEUX, LS. 2013. Relações entre caracteres de raiz e ganhos genéticos diretos e indiretos em populações de cenoura. Horticultura Brasileira 31: 25-29. 